\title{
Indonesia and Africa: questioning the origins of some of Africa's most famous icons
}

\author{
ROBERT DICK-READ*
}

\begin{abstract}
In the author's opinion there have been three far-reaching gaps in the study of Africa's history: 1) Indonesian involvement in East and Central Africa; 2) Links between Madagascar and Eastern and South/Central Africa; and 3) Extension of Indonesian interest to West Africa, particularly Nigeria. He contends that Indonesians (the term applies to 'Insular Southeast Asians') may have begun regular trading to Africa when Greek and Roman demand for oriental spices developed several centuries BCE. The East African 'Zanj' were, in his view, an Afro/ Indonesian race linked with the people of 'Zabag' - Sumatra and Java - later with Srivijaya in particular, whose interest in the gold, copper, iron and other products of Africa were extensive.

Madagascar was only ever of secondary importance to Indonesians compared with mineral-rich Africa. But for centuries the Austronesian-speaking, Afro-Indonesian people of Madagascar maintained regular contact with the mainland giving rise to mixed societies, particularly in the Mozambique-Zimbabwe region. He believes the ancient Zimbabwe culture was in several ways linked with that of Madagascar, and that the vast ruin area of Nyanga was also connected. These cross-channel associations were gradually eclipsed by the domination of Arab-Shirazi colonisation down the East African Coast. There is a wealth of evidence that Indonesians rounded the Cape and sailed to West Africa. Several elements of Nigerian culture generally attributed to East-West overland movements or trans-Saharan Arab traders, are more likely to have reached the lower Niger regions by sea from Indonesia. Among these was the technology enabling the iconic 'bronze' artwork for which Nigeria is famous.
\end{abstract}

Key words: Indonesia. Madagascar. Zimbabwe. Nigeria. Srivijaya. Zanj. Zabag. Outriggers. Goldmines. Plantains. Xylophones. Bronze. Igbo-Ukwu.

The romance of the dhow clings to East Africa's coast, encompassing its history with rich odours of the sea, born inexorably ashore by the gentle kaskasi. Billowing settee sails spread their wings on the horizon, heading for land. Rounding the point into Mombasa harbour, echoing to the sound of drums and pipes and urgent shouts, a dhow drops its canvas and comes to rest in a coterie of bums, baghlas, sambuks and kotirs swinging close to one another in the placid creek. A nakhoda, henna-dyed and eagle-eyed, is rowed ashore to do his business. Jetblack glistening bodies brush by, heaving boriti poles to the water's edge.

\footnotetext{
* Robert Dick-Read is author of The phantom voyagers: evidence of Indonesian settlement in Africa in ancient times, (Thurlton Publishing) Winchester, 2005). thurlton.publishing@ntlworld.com.
} 
Long carts with creeking wheels trundle noisily through the streets, piled high with boxes and furnishings of many sorts. Boys in white gelabias and colourful kofias play mischievous games. Young ladies in black, with delicate ankles and pretty dark eyes, glance enquiringly from the folds of their bui-buis. There is a heavy sensuality in the heat and din and sweatfilled atmosphere of the ancient harbour. The nakhoda is soon lost in the bustling humanity of the narrow alleyways and clamouring warehouses.

This was the Mombasa I knew over fifty years ago when I used to spend hours buying carpets from the likes of Sharif Shatry and Sheikh Mohammed. It is easy to see why the most pungent images of the Indian Ocean are those brought about by the dhows - among the most evocative and romantic vessels ever built. In their hey-day there were at least thirty varieties regularly plying the waters - from Kilwa to Kuwait, Mombasa to Mangalore, Bombay to the Bajun Islands ... balams, batels, zaimas, and zarooks - pattamars and padaos, dhangis and ganjas - and many more besides.

But one must not let the dhows in all their glory obscure the importance of generations of ships from other parts of the ocean that came before them that came, and in some cases slid into the past unnoticed, like the dinosaurs of the Jurassic who once ruled unopposed in their watery world.

Who knows what the first Indian Ocean ships were? We have some evidence, and can make some guesses. Hide or bundle boats have been used in Mesopotamia since at least the fifth millennium before the common era $(\mathrm{BCE})$, though whether these put to sea or not we have no idea. ${ }^{1}$ Centuries later, the Egyptians must have been among the earliest seafarers in the region. The brilliant construction of Cheops' river-boat buried near his pyramid four and a half thousand years ago testifies to their ingenuity and craftsmanship; ${ }^{2}$ as do Queen Hatshepsut's manyoared, rectangular-sailed ships despatched to the illusive Land of Punt a thousand years later. The rivers of Mesopotamia, the Indus, and others in northern India teemed with vessels of one sort of another in the second millennium BCE; but so far as we know these ventured only a few hundred miles down the Indian coast, as far as the ancient Harappan ports of Lothal and Bhagatrav. ${ }^{3}$

Or did they go further? Were ships already criss-crossing to the far side of the Indian Ocean when the great civilisations of Mesopotamia thrived? Cloves from the Moluccas have been found at Terqa on the Middle Euphrates, dated to about $1700 \mathrm{BCE} .{ }^{4}$ Conversely, remains of sheep or

1 S McGrail, Boats of the World. (OUP, Oxford and New York, 2001) p. 56.

2 N Jenkins, The boat beneath the pyramid: King Cheops' royal ship, (Thames and Hudson/Holt Rinehart and Winston, London and New York, 1980).

3 M Wheeler, The Indus civilisation 1979 (Cambridge University Press, Cambridge, 1979), p. 65

4 G Buccellati, Correspondence. 11th April 2002; Also see MW Chavalas, Terqa and Haradam: A comparative analysis of old Babylonian period houses along the Euphrates (University of Wisconsin Press, Wisconsin, 2003). p. 2. 
goats - Middle Eastern animals - have been found on Timor, dated to c. 1,500 BCE. ${ }^{5}$ Even if cloves came via the 'silk route' and the sheep were driven to Southeast Asia overland, which is very unlikely, lengthy seatrips between the mainland and the islands would have been essential; so it is possible that long voyages across the Indian Ocean were being undertaken far earlier that is generally recognised. ${ }^{6}$

According to the Biblical book of Kings, in about 1000 BC:

Hiram sent in the navy his servants ... And they came to Ophir, and fetched from thence gold, ... and brought it to King Solomon (and) ...once every three years, the ships of Tarshish came bringing gold and silver, ivory, apes and peacocks.... ${ }^{7}$

Talk of peacocks, in particular, suggests that some of the goods must have come originally from India; and the linguistic evidence points specifically to southern India. The names adopted in the Middle East for apes (kapim), and peacocks (tukim), and later the words for rice (oryza), and ginger (zingiber) were all adaptations - not of the Sanskrit or Pali languages of Aryan India - but of Dravidian words from the Tamil south. ${ }^{8}$

Herodotus related how, in the reign of Pharaoh Necho, c. 600 BCE, a fleet of Phoenician ships (built in the Mediterranean, sent through Necho's canal from the Nile to the Red Sea were the first to circumnavigate Africa. Before the turn of the first millennium, Greek and Roman ships - built on Egypt's Red Sea coast - traded regularly with southern India. Lists of goods for the Mediterranean trade included food and drink, textiles and clothing, household items, tools, pepper and other spices, aromatics, drugs and dyes, slaves; and ornaments such as a sensuously exquisite ivory figurine from India found buried in the ashes of Pompeii. Huge demand arose among wealthy Romans for fine Indian and Chinese cloth, unguents, perfumes, pearls, and precious stones. Muslins and cottons and silks were sold at fabulous prices; the last of them - silk - being literally worth its weight in gold during the reign of the third century Caesar Aurelian. ${ }^{9}$

$5 \mathrm{~J}$ Reade, Introduction to Indian Ocean in Antiquity (Kegan Paul, London, 1996), p. 19; IC Glover, Recent Archaeological Evidence for early Maritime contacts between India and Southeast Asia, (1993) p. 138: IC Glover, "Aksumite overseas interests" in J Reade, The Indian Ocean in Antiquity p. 77; Also conversation with Dr Kinkel at British Museum.

6 W Mahdi, "Linguistic and Philological date towards a chronology of Austronesian activity in India and Sri Lanka" in R Blench and M Spriggs (eds.), Archaeology and Language (Routledge, London and New York, 1997 and 1999), p. 213 and ff. for a similar view.

7 Kings 1: 9, verses 27-28; and Kings 1:10, verse 22.

8 V Kanakasabhai, The Tamils Eighteen Hundred Years Ago. (Higgenbotham, Madras, 1904), p. 31 See also: note 25 below. (Mahdi,) Dravidian words for 'boats'.

9 KR Hall, Maritime and State Development in Early Southeast Asia, (University of Hawaii Press, Honolulu, 1985), pp. 27-36, 59. 
Gold and specie flowed from Rome to Asia. In AD 77, lamenting the extravagance and reckless spending of Rome's rich and famous, Pliny wrote despairingly that there was "no year in which India did not drain the Roman Empire of a hundred million sesterces ... so dearly do we pay for our luxury and our women." Tiberius grumbled that "the ladies and their baubles are transferring our money to foreigners." And even during Christ's lifetime, the emperor Augustus, shamed by the widespread lowering of standards, passed a law forbidding the wearing of transparent Indian silks on the grounds of indecency. One scholar has argued that the period "when the Classical civilisations of the Mediterranean encountered Buddhist India and Han China" should be looked upon as the beginning of the World System! ${ }^{10}$

There were two spices sent to Rome from the Orient whose Southeast Asian origins were disputed as far back as the third century BCE. These were cinnamon and cassia. ${ }^{11}$ Herodotus thought they came from Arabia, and so did the famous author of the History of plants, Theophrastus. Agatharchides said Sabaea; Philostratus, India; Strabo simply said the 'cinnamon-country', probably meaning India. An anonymous papyrus said from 'Trogodytica' (meaning North-east Africa somewhere). But in his Natural History Pliny the Elder (CE 24 - 79) explained:

\begin{abstract}
In fact cinnamomum, which is the same thing as cinnamum, grows in 'Ethiopia', which is linked by intermarriage with the Cave Dwellers. These buy it from their neighbours and bring it over vast seas on rafts which have no rudders to steer them, no oars to push them, no sails to propel them, indeed no motive power at all but man alone and his courage ... They say that their traders take almost five years there and back, and that many die. On the return journey they take glassware and bronzeware, clothing, brooches, bracelets and necklaces so here is one more trade route that exists chiefly because women follow fashion.
\end{abstract}

Following delivery to Opone and other ports in the Horn of Africa, these goods were shipped to the Mediterranean in Arab vessels. For many centuries BCE Arab fleets flourished in the Red Sea; but as the Mediterranean trade with India and the Far East grew, the sturdily built vessels of Rome and Greece proved to be better equipped to handle the boisterous direct crossings to India than the sewn ships of Arabia, a factor that led to a decline in Arabian shipping in the centuries prior to Islam.... A decline, however, that was not matched by Sassanian fleets in the Persian Gulf for whom the coastal journeys around India became frequent, even

10 IC Glover, Recent Archaeological Evidence for early Maritime contacts between India and Southeast Asia. p. 131.

11 L Casson. Trans. The Periplus Maris Erythraei: text with introduction, translation, and commentary, (Princeton University Press, Princeton, N J. 1989), p. 123. The best general account of the spice trade in this period is still JI Miller, The Spice Trade of the Roman Empire, (Oxford, Clarendon Press. 1969): Also see EH Warmington, Commerce between the Roman Empire and India. (1928, revised in 1974 and republished in 1995) L Casson, "Ancient Naval Technology and the Route to India" in V Begley and RD de Puma (eds.) Rome and India - The Ancient Sea Trade, Oxford University Press, New Delhi reprint, 1991). 
commonplace, by the middle of the first millennium of the common era (CE). The first Arab seaborne mission to China was in $724 \mathrm{CE} .^{12}$

But what were Pliny's strange raft-like vessels that brought the cinnamomum? Were they Indian? Little is known of Indian ships of the era. The Greek 'master' who wrote the Periplus of the Erythraean Sea in the mid-first-century CE mentioned four specific types of 'Indian' ships. Two of them, the trappaga and the kotymba were most likely inshore pilot boats. But he wrote also of two larger ships in southern India:- “... sangara, that are very big dugout canoes held together by a yoke, as well as for the very big kolandiaphonta that sail across to Chryse and the Ganges region." 13

Lionel Casson, in his translation of the Periplus Maris Erythræi, pointed out that in Tamil-form, sangara equals shangadam, which the Portuguese borrowed as jangar or jangada meaning a 'raft', or more specifically, a "double platform canoe made by placing a floor of boards across the two boats."This substantially agreed with Warmington's view that a sangara was apparently “... very large, made of single logs bound together, apparently double canoes either Malay in origin or corresponding to the jangar of Malabar today." Most experts seem to agree that the sangara is likely to have been derived from an Indonesian twin-hulled design similar to some of the multi-hulled vessels in which mariners explored much of the Pacific.

So, were cinnamomum cassia Blume and Cinnamomum zeylanicum Nees carried to the Horn of Africa directly by Indonesian sailors on these perilous rafts? It is very possible that such journeys provided Indonesians with a raison d'être first for visiting, and subsequently settling in East Africa, from where they later set out to people Madagascar.

What of the kolandiaphonta mentioned in the Periplus? Linguists find a connection between this word and the name by which Indonesian ships were known to the Chinese - Kun-lun-po - meaning 'ships of Kunlun', the Chinese name for Sumatra or Java. Both Anthony Christie ${ }^{14}$ and James Hornell, thought they "probably had a close kinship with the

12 M Laffan, "Finding Java: Muslim Nomenclature of Insular Southeast Asia from Srivijaya to Snouk Hurgronje”, (Asia Research Institute paper No 52. 2005). Laffan is quoting Wolters.

13 The best general accounts of boats and shipping in this period can be found among the following sources: L Casson. The Periplus Maris Erythraei..., pp. 128, 203 - 230; L Casson, "Ancient Naval Technology and the Route to India" (U. of Wisc. edition 1991;

J Hornell, Water transport: origin and early development, (Cambridge University Press, Camrbidge, 1946); GF Hourani, Arab seafaring (Revision: John Carswell. Princeton University Press, Princeton NJ, 1995; RK Mookerji, Indian shipping: a history of the sea-borne trade and maritime activity of the Indians from the earliest times, (Longmans. 1912): See other sources in the Appendix.

14 A Christie, in Minutes of the African History Seminar S.O.A.S. 11.4.1959 (unpublished). 
two-masted Javanese outrigger ships of the (eighth century) Boro-Budur sculptures, seeing that the Periplus distinctly states that the kolandia traded to Chryse". It is now generally accepted that rather than being an Indian name for an Indian vessel kolandiaphonta was a straightforward transcription of the Chinese term 'Kun-lun-po'. ${ }^{15}$

As a maritime nation this leaves India out on a limb, and one wonders whether, in the millennia following the decline of the Indus civilization, Indians were ever great off-shore sailors. ${ }^{16}$ The Indian maritime historian, Radha Kumud Mookerji, writing in the early 1900s, was confident that they were. ${ }^{17}$ "I have already said," he wrote, "that though Indian literature furnishes rather meagre evidence directly bearing on Indian shipping and shipbuilding, it abounds with innumerable references to sea voyages and sea-borne trade and the constant use of the ocean as the great highway of international intercourse and commerce..." But what sort of references was he alluding to? Mookerji delved deeply into the Jatarkas, and the Mahabharata, and a treatise on astronomy/astrology - the Binhat Samhita - all of which were written or up-dated as recently as the fifth and sixth century A.D.. He came up with many obscure poetical myths and legends of great maritime feats, including one from the Digha Nikaya which stands out for the fact that it "distinctly mentions sea voyages out of sight of land" - seemingly a rare and special occurrence. His stories are shot through with countless references to shipwrecks and other dramatic disasters such as; "His ship, however, sprang a leak in mid-ocean, but he is miraculously saved by a kind fairy in a magic ship filled with the seven treasures..." And on the evidence of just one Sanskrit work, the Yukti Kalpataru, Moorkerji made a case for there having been huge ocean-going ships built in ancient India, carrying seven and eight hundred, even a thousand, people. But surely these were ships of fable? Collectively the references to early ocean-going shipping leave frustrating question-marks, and suggest that even if the ships of Aryan India did venture out to sea, they were poorly built, and their sailors were inadequate for the task.

Mookerji, in his book, depicts one of the large ships painted on the walls of the sixth or seventh century A.D. caves at Ajanta in northwest India. The Ajanta boats tell nothing about truly 'ancient' shipping. Several features on the boats that are shown - for instance the artemon foresails suggest that they could have been strongly influenced by Greek or Roman ships, and offer less than no proof that they were 'Indian'. The highpoint of Mookerji's work, to his way of thinking 'proving' India's maritime proficiency, is his description and portrayal of the magnificent 'Indian'

15 J Hornell, Memoirs of the Asiatic Society of Bengal Vol 7 1920. Part IV p $215-224$. The Classes of Vessels Employed by Indians in Ancient Days Prior to Portuguese Maritime Dominance.

16 For instance, see EH Warmington, The Commerce between the Roman Empire and India, (London revised 1974) p. 65.

17 RK Mookerji, Indian Shipping: A History of The Sea-Borne Trade And Maritime Activity Of The Indians From The Earliest Times. (Longmans, 1912). 
ships carved on the famous 'Indian' temple at Borobudur in Central Java. But though Indians may have played an important part in designing and building the famous Buddhist temple, it has subsequently been shown, beyond any doubt, that the seven beautiful outrigger ships depicted on the walls were not Indian - but Indonesian.

In China, mariners took to the open oceans surprisingly late in history. Though a huge variety of vessels of all sizes had undoubtedly been plying China's rivers and coasts for centuries, they did not apparently go far out into the oceans until the third quarter of the first millennium $\mathrm{CE}$. Until that time the Chinese 'farmed out' their international traffic to Indonesians. ${ }^{18}$

In the seventh century the famous Chinese pilgrim, I Tsing went, with others, to India on vessels provided by an Indonesian ruler. The same I Tsing referred to visitors to Tongking as people from the Kun-lun countries, meaning 'Indonesians'. ${ }^{19}$ But by then Kun-lun merchants were sailing annually to Canton. By the middle of the eighth century China was building merchant ships of nearly 600 tons - rather larger than the average Spanish ship of the Armada 800 years later. Sailors lived on them with their wives and families; there were 'gardens' on board, as well as the owner's slave-girls, and musicians. But it seems from documents compiled in the Thang dynasty by Wang Tang that these ships were owned by merchants plying for trade up the coast and on the rivers, rather than across the oceans. ${ }^{20}$

Endorsing the view that these large Chinese ships did not venture far from the coast, Wang Tang specifically said that "The sea-going junks (hai po) are foreign ships." 21 There is at least one Chinese record relating that foreign ships (Indonesian) were sometimes chartered to merchants from other parts of Asia. ${ }^{22}$ This situation may have gone on for centuries. In their introduction to the story of Chau Ju-Kua, Rockhill and Hirth concluded that Cantonese junks did not visit southern India until the twelfth century CE. ${ }^{23}$ But this did not stop Chinese missionaries and merchants travelling far and wide on 'foreign' ships throughout the first millennium, and Jo Needham was able to write:

18 For information on anything to do with China, see J Needham, Science and Civilisation in China, (Cambridge University Press, Cambridge, 1954) is essential reading.

19 OW Wolters, Early Indian Commerce, p. 199. Chinese writers in the 8th/9th century described the Kun-lun people as being very black, curly headed, and eaters of human flesh.

$20 \mathrm{~J}$ Needham, Science and Civilisation in China - Nautical Technology Cambridge, p. 452 Note b.

21 Ibid., pp. 451-453

22 OW Wolters, Early Indian Commerce, pp. 151-157; 169; 222-225 This book is a fund of important information on S.E. Asia; See also KR Hall, Maritime and State Development in Early Southeast Asia, (University of Hawaii Press, Honolulu, 1985).

$23 \mathrm{~J}$ Chau On the Chinese and Arab Trade in the 12th and 13th centuries, (Translated by Friedrich Hirth and W.W. Rockhill, Literature House Ltd, Taipei, Taiwan, 1964). 
It is arresting to think that Chinese merchant-officials walked with Roman citizens from Greece, Syria and Egypt on the quays of Arikamedu (in southern India). ${ }^{24}$

The nautical history of the Southeast Asian islanders is probably the oldest in the world; they had, after all, been crossing deep water for 60000 years, since the earliest migrants had managed to migrate from Sundaland to Sahulland to reach Australia. ${ }^{25}$

Much later, about 5000 years ago, when 'Austronesian' speaking seamen migrated from Formosa and began to explore the islands of the Pacific, many of them also spread their language westward to the islands bordering on the Indian Ocean, and even further. James Hornell, one of the twentieth century's most respected marine ethnographers, wrote an article asserting that Polynesians, i.e. Austronesian-speakers, became established in southern India in pre-Dravidian times. His opinion was based on the geographical distribution of outrigger canoes:

(A) point of the highest importance in this connection is the fact that in common with Polynesians, they employ a single outrigger on their canoes, in striking contrast to the double form so characteristic of Malaysian small craft ... It is not surprising that there we find the Polynesian boat forms in great variety ... in common with peculiar Polynesian fishing devices, in continued high esteem by the local fishermen and divers.

After detailed discussion he concluded:

I incline to think that these Parawas (of southern India) represent a part of that fierce Naga race described by ancient Tamil writers as in possession of the coast districts and with Negapatam as their chief town when the Tamils first arrived in the south". I would then identify the Nagas with an ancient coastal people of Polynesian affinity. ${ }^{26}$

This is a view supported by the fact that Tamil words such as padavu, padangu, or hadagu for 'ship' or 'boat' are derived from Austronesian padaw or perahu. ${ }^{27}$

If Hornell was correct, Austronesian speaking mariners - let us call them 'Indonesians' - were moving freely in the Indian Ocean centuries before the Mediterranean trade of which we have written above, making the archaeological evidence of 'cloves from the Moluccas' and 'sheep to Timor' a less fantastic possibility.

$24 \mathrm{~J}$ Needham, Science and Civilisation in China Volume 4, p. 443.

25 P Bellwood, Prehistory of the Indo-Malaysian Archipelago. (University of Hawaii Press, Honolulu, Revised edition 1997). For a general background of the region's history, and much detail, this is essential reading. P Bellwood, The Peopling of the Pacific. In Scientific American' (date and issue unknown).

26 J Hornell, Memoirs of the Asiatic Society of Bengal, Vol. 7, 1920 - Part V. pp. 225 - 235 The Light Shed upon Eastern Ethnological Problems by Indian Boat Designs.

27 W Mahdi, "The Dispersal of Austronesian Boat forms in the Indian Ocean in Archaeology and Language" in R Blench and M Spriggs (eds.), Archaeology and Language (Routledge, London and New York, 1997 and 1999), p.172. 
Hornell's Polynesian hypothesis is not given much help by archaeology in India, where ancient ship-remains are virtually non-existent. But in Indonesia there is substantial archaeological evidence dating back at least to the early part of the first millennium CE. The oldest known Indonesian ship remnants, recorded by Pierre-Yves Manguin, are pieces of a plankbuilt boat at Pontian, on the south-west corner of the Malay peninsular carbon-dated to the third - fifth century A.D. ${ }^{28}$ Parts of a similar boat of about the same period have been found in southern Thailand. And in southern Sumatra, near Palembang, strakes clearly belonging to a large and sturdy hull, dated to between the fifth and the seventh century, have been unearthed. A remarkable aspect of all of these ancient relics is that the standard stitched-plank, lashed-lug and dowel construction technology appears to have been used by Indonesian boat-builders more or less unchanged for the next fifteen hundred years.

Also in southern Sumatra archaeologists have found two quarter-rudders measuring $9 \mathrm{~m}$ and just under $7 \mathrm{~m}$ long respectively - much the same as those still in use on large boats today and probably dating from the first half of the first millennium CE. Contemporary timber sections, reconstructed, have produced a single strake over $47 \mathrm{ft}(15,23 \mathrm{~m})$ long from which it has been estimated that the vessel was 21-23 m long, and narrow - possibly similar to the elegant fighting-ships called kora kora, paddled by as many as 300 men ranged in double banks on the outriggers, ${ }^{29}$ that still prowled the Indonesian islands long after the arrival of the Portuguese and Dutch.

Earlier we mentioned that Hornell and Christie believed the large ships depicted on the walls of Borobudur traced their ancestry back to the kolandiaphonta of the Periplus, alias the K'un-lun-po of the Chinese which, so far as we know, did not have outriggers. Whether that was the case or not, Adrian Horridge thinks the Borobudur ships were ancestral to the swift kora kora: ${ }^{30}$ and if he is right, these large outrigger vessels would have been the macro jet aircraft of their age that carried Indonesian influences far and wide across the Indian Ocean over a period of hundreds of years. This interpretation gained support from the successful voyage of Philip Beale's traditionally built, iron-free and engineless, Samudra Raksa, a

28 Pierre-Yves Manguin's work on the maritime archaeology of Southeast Asia is essential reading - starting with the three articles listed below: P-Y Manguin, Pre-modern Southeast Asian Shipping in the Indian Ocean: The Maldive Connection. 'New Directions in Maritime History Conference' Fremantle. December 1993; P-Y Manguin, "Southeast Asian Shipping in the Indian Ocean During the First Millennium A.D." in Tradition and Archaeology. ed. Hamanshu Ray and Jean-Francois Salles. See:' Proceedings of the International Seminar - Seafaring in the Indian Ocean'. New Delhi. 1994; P-Y Manguin, "The Southeast Asian Ship: An Historical Approach" in Journal of Southeast Asian Studies, 11(2), 1980, pp. 266-276.

29 A Horridge, The Prahu (Oxford University Press, Oxford, 1981), p. 4.

30 Ibid., p. 1. 
'replica' of one of the Borobudur ships, which safely completed a voyage of $17600 \mathrm{~km}$ from Java to Madagascar and on to Ghana in 2003. ${ }^{31}$

We know that Indonesians have been familiar with the Western Indian Ocean since sometime in the early part of the first millennium CE, if not before. The fact that Austronesian speakers peopled Madagascar is not disputed. But questions remain: When did Indonesians first cross the Indian Ocean? What route did they take? Did they settle on mainland Africa before going on to Madagascar? Where in Indonesia did they come from? Who were they? What motivated them?

Some of the answers are bound to remain conjectural. We have suggested they may have been Pliny's 'raft'-men bearing spices from Southeast Asia; and we have even suggested that the spice trade might date back to the second millennium BCE (viz. cloves to Terqa). As for their route, one possibility is that Indonesians came directly across the Indian Ocean from Java to Madagascar. But as they apparently never discovered the Seychelles or any of the other Mascarene islands, it is more likely they went further north, passing through the Maldives where evidence of old Indonesian boat design and fishing technology lingers even now. ${ }^{32}$

Though we cannot be sure that Madagascar was not 'discovered' at an earlier date, the consensus seems to be that the main settlement was not until the fifth to seventh century $\mathrm{CE}$, and only after the new inhabitants had spent a prolonged period in Africa where there developed some sort of 'Afro-Indonesian' or 'Afro-Malagasy' race. ${ }^{33}$

If we stop to ask who these mixed Indonesian/African people might have been, we have to give serious consideration to the possibility that they were none other than the famous 'Zanj', after whom the Western Indian Ocean (the Bahr ez-Zanj) and most of the East African coast (the Ard az Zanj, and the Sufala of the Zanj) was named by Islamic Arab writers - and there are a number of factors to support such a contention. The old Arab name for Sumatra and/or Java was 'Zabag', 'Zabaj' or 'Zanaj'. On what may be an eleventh century copy of a map commissioned in the early ninth century by Abbasid Caliph al-Ma'mun, 'the lands of Zabaj' are placed on the African coast below the orthographically similar 'lands of Zanj'. ${ }^{34}$ Then there is Idrisi's famous passage (trans. Trimmingham):

31 Details of this journey can be found on the internet. Google Samudra Raksa. The Borobudur Ship

32 P-Y Manguin, Pre-modern Southeast Asian Shipping in the Indian Ocean: The Maldive Connection. 'New Directions in Maritime History Conference' Fremantle. December 1993.

33 KA Adelaar, "Malagasy Culture-History: some Linguistic Evidence" in J Reade (ed.) The Indian Ocean in Antiquity, p. 489. H Deschamps, Histoire de Madagascar. (4th ed. Éditions Berger-Levraut, Paris, 1972), p.25

34 M Laffan, "Finding Java: Muslim Nomenclature of Insular Southeast Asia from Srivijaya to Snouk Hurgronje”, (Asia Research Institute paper No 52. 2005), p. 22. 
The people of the Zabaj islands [also] travel to the Zanj in both small and large ships and engage in trafficking in their goods because they understand each other's language.... ${ }^{35}$

The British Orientalist, Anthony Christie, went further, saying that:

The Arab word zang or zenj used for 'negro' may not be Arabic ... an apparent Chinese form occurs as early as 607 AD. There is no doubt that this seng-ch'i was typically S.E. Asian. ${ }^{36}$ [Zanj] could possibly be a S.E. Asian word. ${ }^{37}$

The names 'Zangenae', Zingis', 'Azania', 'Zanj', 'Zand', and 'seng-ch'I', frequently cropped up in writings of the Greeks, Romans, Arabs, Persians, and Chinese since the early part of the first Millennium CE, paralleling Indonesian interest in Africa and the settlement of Madagascar.

There are other reasons for thinking the Zanj were at least part-Indonesian. When Arabs first encountered them, the Zanj were occupying the offshore islands of Pemba and Zanzibar, demonstrating that they must have been competent sailors - a feature not normally associated with East Africa's Hamitic, Cushitic, Bantu or San tribes. ${ }^{38}$ And there is no reason to think that they did not already use boats with outriggers such as the traditional ngalaua of Indonesian design. These vessels are still found from the Bajun Islands to the Comoros and Madagascar. The Zanj did not speak Arabic; and though there may possibly have been a few Bantu words, their language (from what little is known of it) was apparently not of Bantu origin. ${ }^{39}$ They used strange fishing techniques similar to some used in Indonesia. Masudi wrote that the Zanj were skilled iron workers and hunters, and that they traded ivory to the Far East. ${ }^{40}$ As late as the sixteenth century. ${ }^{41}$

35 JS Trimmingham, "The Arab Geographers and the East African Coast" in. HN Chittick and RI Rotberg. East Africa and the Orient: Cultural Synthesis in Pre-Colonial Times, (Africana Publishing Company 1975), p. 126.

36 M Laffan, Princeton University, in correspondence, writes: "I don't think this is beyond doubt at all. Zenjis/Jenggis are mentioned in Javanese inscriptions of the 9th and 10 th centuries and seem to refer to foreign African visitors."

37 A Christie, in Minutes of the African History Seminar S.O.A.S. 11.4.1959 (unpublished).

38 Some commentators point out that we do not know if this was the case 1000 years ago. But if the indigenous people were ever fine seamen it is likely that they would have been aware of the Comoro Islands - probably from the occasional eruption of Mount Karthala - and would have peopled Madagascar before the arrival of Austronesian speaking people from the east. But the evidence does not point to this.

39 M Tolmacheva, 'The Zanj Language', Ktswahtlt, 45(1), 1975.

40 M Tolmacheva, "They Came from Damascus in Syria" in The International Journal of Historical Studies, 12(2), 1979, p 263; M Tolmacheva, Dictionary of the Middle Ages v12 (1989), p. 739.

41 For general reading on the Zanj the following are among the most useful: $\mathrm{M}$ Tolmacheva, "The African Waq Waq: Some Questions regarding the Evidence" in Bulletin d'Information Fontes Historical Africanae, No. 11/12 1997/8, p. 9; M Tolmacheva, "Toward a Definition of the Term 'Zanj" in Azania, XX1, 1986; M Tolmacheva, "The Origin of the name 'Swahili" in Tanzania Notes and Records 77/78, 1976; JS Trimmingham, "The Arab Geographers and the East African Coast" in. HN Chittick and RI Rotberg. East Africa and the Orient: Cultural Synthesis in Pre-Colonial Times, pp. 131-132; J Knapper "The Trade Language of the Indian Ocean 1979" (?). This 'pull' was sent to me by Jan Knappert. It has neither date, nor page numbers. The article deals in general with trade as title suggests. 
From what part of Indonesia would these migrants have come?

Austronesian language experts such as Sander Adelaar ${ }^{42}$ stand by Otto Chr. Dahl's research indicating that the language of Madagascar is derived from Maanjan, the language of riverine people in the Barito valley of South East Borneo. ${ }^{43}$ The introductory lines of seventh century inscriptions found on Bangka Island (opposite the Musi river on the banks of which lay the capital of Srivijaya, Palembang) are in a Barito-like language that seems also to be a form of pre-Malagasy. ${ }^{44}$ But a cursory glance at the modern culture and history of the Maanjan (riverine Dyaks, canoe builders of note, but so far as anyone knows, never mariners who might have ventured far) must throw doubts on whether they themselves were the emigrants. ${ }^{45}$

Although Otto Chr. Dahl was the first to propose the hypothesis that the Malagasy language was rooted in Maanyan, he was equally convinced that it was Bajau mariners - probably those who had settled on Bangka Island - who carried Indonesians to Africa and Madagascar. ${ }^{46}$ It is well recognised, however, that the hugely scattered diaspora of Bajau seanomads lives in a sprawling linguistic hotchpotch, the dialects of nomadic groups often differing radically from those of sedentary groups; and the latter frequently acquiring the languages of their 'hosts'. ${ }^{47}$ Thus it is quite conceivable that if Bajau once settled in the Barito estuary, (here one is reminded of Dahl's comment: "Il y a dans le Malgache des éléments qui semblent nous orienter vers Célèbes"48) they may well have acquired Maanyan as their primary language, thus allowing us to reject the view that riverine Dyaks were the (unlikely) settlers of Madagascar.

To resolve this dilemma it might have been hoped that genetic studies carried out in 2005 would have provided a clear-cut answer. But no such luck. DNA samples were taken in Banjarmasin on the Barito river; others $1600 \mathrm{~km}$ north in Kota Kinabalu; and although the authors state boldly: "The closest single island Southeast Asian or Oceanic population to the Malagasy is that from Banjarmasin." A few lines further on they say (referring to Banjarmasin and Kota Kinabalu): “... it was observed that there

42 KA Adelaar, in correspondence, May 2006: "Dahl was basically right in tracing the origins of ther Malagasy language to the Southeast Barito language group in Borneo, to which Maanyan belongs."

43 OC Dahl, Malgache et Maanjan: Une comparaison linguistique, (Egede Institutttet, Oslo, 1951).

44 KA Adelaar, "Malagasy culture-history: some linguistic evidence" in J Reade, (ed.) The proceedings of the conference on The Indian Ocean in Antiquity, (Kegan Paul London, 1996), p. 492.

45 AB Hudson, Padju Epat - The Ma'anyan of Indonesian Borneo. Michigan State U. 1972. AB Hudson and M Judith, The Ma'anyan of Paju Epat in Essays on Borneo Societies. Hull monograms on S.E. Asia 7, 1978.

46 OC Dahl, Migration from Kalimantan to Madagascar, (Norwegian University Press, Oslo, 1991). Pp. 98, 100, 120, etc

47 D Sopher. Op cit pp. 179-183.

48 OC Dahl, Op Cit. p. 372. 
is no significant difference between the two Borneo populations. "W9 While a Borneo link with Madagascar is acceptable, the probability of the Maanyan of the Borito river having migrated to and mingled with the people of Kota Kinabalu at any time is very unlikely. This adds credibility to Dahl's view that the Borneo/Malagasy link was effected by Bajau mariners - in this case Bajau who had acquired the Maanyan dialect.

Analysis of the various 'Sea People' of Indonesia adds further support to this hypothesis. Whereas most of the smaller 'Orang Laut' sukus might not have made the best material for the Srivijayan navy, nor to undertake long distant voyages across the Indian Ocean, those of South Sulawesi, ${ }^{50}$ present a different picture, particularly the forebears of the Bajau, (or Bajō, with the accent heavily on the 'o') Bugis, Mandar and Makassar who have dominated the Indonesian maritime scene for centuries. ${ }^{51}$ In fact one of the very few linguistic links between Africa and Indonesia seems to confirm this: in Makassarese, Buginese and Mandar a canoe's outrigger pole is baratang, or buratang. In Makassarese the connecting piece between the outrigger pole and the float is tenko. ${ }^{52}$ In north eastern Australia (one of the regions from which Bugis, Bajau and Makassarese fishermen used to gather trepang for the Chinese market) a doubleoutrigger canoe is tango. ${ }^{53}$ While on the other side of the Indian ocean, in Kiswahili and Shingazija (Comoros), an 'outrigger' is tengo or mtengo. These names are too similar to be explained merely by 'coincidence'. ${ }^{4}$

If there is a valid link with East Africa, between the Bajau and their closely associated suku the Bugis, Mandar and Makassarese, one is tempted to speculate on the origin of some of the names one finds on the African coast. Look, for instance, at the Bajun Islands. Vinigi Grottanelli devoted seven pages in his 'Pescatori Dell'Oceano Indiano' trying to fathom the origin of the name 'Bajun'; but still left the question open. ${ }^{55} \mathrm{He}$ pointed out that 'Bajun' does not follow the normal Bantu rules: the people are never known as the Wa-Bajuni or M'Bajuni. They are the 'Bajun' or 'Bajuni'

49 M Hurles, B Sykes, M Jobling, P Foster, The Dual Origin of the Malagasy in Island Southeast Asia and East Africa: Evidence from Maternal and Paternal Lineages. American Journal of Human Genetics, 76, 2005, pp. 895, 899-900.

50 OC Dahl, in the penultimate paragraph of his book Malgache et Maanjan hinted at a possible connection between Malagasy and Southwest Sulawezi. "Il y a dans le Malgache des éléments qui semblent nous orienter vers Célèbes" (p.372)

51 DE Sopher, The Sea Nomads - A study of the Maritime boat people of Southeast Asia ([1965], National Museum of Singapore, Reprint 1977).

52 A Horridge, The Prahu, Bottom of Table 1 page 88 (No's 47-48) for Sulawezi.

53 Dictionary of the World's Watercraft. The Mariner's Museum 2000. p. 572

54 KA Adelaar, "Malagasy culture-history: some linguistic evidence" in J Reade, (ed.) The proceedings of the conference on The Indian Ocean in Antiquity, shows a compass point system (page 491) that he believes may have been developed in Palembang, 'North' being towards the sea; 'South' towards the interior, etc. 'South-East' is termed tengara which, he says: "must be a loanword (although we do not know its history ...)". Is it possible that it points towards the locality from which came the 'outrigger' ships that were the mainstay of Srivijaya's vitally important navy?

55 VL Grottanelli, Pescatori Dell 'Oceano Indiano. (Rome, 1955) p. 8 ff.

TD, 2 (1), July 2006, pp. 23-45 
pure and simple. The Bajun are fishermen, and amongst other things they fish for 'sea-cucumbers', or trepang, an item for which the Bajo of Indonesia used to travel thousands of miles to satisfy the pallets of Chinese gourmets. The Bajun of Africa have an unusual way of catching turtles using a remora sucker-fish, similar to methods in parts of Melanesia, Japan, and northern Australia. James Hornell relates how the Bajun came to be the builders of the famous East African Mtepe which possibly has Indonesian ancestry. ${ }^{56}$ Throughout Indonesia there are numerous Bajau toponyms where these itinerant mariners once settled. ${ }^{57}$ One has to ask: Is the name 'Bajun' just another of these toponyms?

Next, in the Standard English/Swahili Dictionary one finds the translation for Madagascar:- "Madagascar, n. Buki, Bukini."

Vinigi Grottanelli, as bewildered by 'Buki' as he was by 'Bajun', said of the term 'Buki': "As far as I know this remarkable name has never been explained"; and Gabriel Ferrand wrote:- "The origins of this denomination remain obscure: the phoneme does not resemble Bantu". ${ }^{58}$ Is the Swahili 'Buki' derived from the presence of the 'Bugi' or 'Bugis' of Sulawesi?

Similar arguments can be made for the island of Manda which seems to have been settled since the early seventh century by non-Islamic seagoing people who used Sassanian glass, Indian pottery, and Chinese porcelain. ${ }^{59}$ Is its name derived from the Mandar of Sulawesi?

And finally, where did the name 'Madagascar' come from? Marco Polo is generally credited with naming the island at the end of the thirteenth century, when he referred to it in his writing as Magastar, ${ }^{60}$ said to be (without any evidence) a corruption of Magadoxo, or Mogadishu. He visited neither Madagascar nor Mogadishu personally. His frequently inaccurate descriptions were based on hearsay gathered from Arab merchants. He correctly described Madagascar as one of the largest and most fertile islands in the world; so how did he confuse it with one of the driest, drabbest, towns in the Horn of Africa? Is it not more likely that Magastar or Madagascar is derived from Makassar - a name most probably as old as the tenth or eleventh century Bugis epic myths, ${ }^{61}$ and possible even older?

56 J Hornell, "The Sea-going Mtepe and Dau of the Lamu Archipelago" in Mariners Mirror, Vol. 27, 1941.

57 D Sopher, Op cit, p. 162.

58 V Grottanelli, Op cit., p. 15.

59 M Horton and J Middleton, The Swahili: the landscape of a mercantile society, (Blackwell, Oxford, 2000).

60 M Polo, Travels. (Ed. W. Marsden 1946). p. $391 \mathrm{ff}$

61 Anthony Reid, Author of: Charting the shape of early modern Southeast Asia (1999), in an email 28th Feb 2006. Reid was writing from memory, and did not give a precise reference. Reid, Anthony. The Rise of Makassar. Review of Also: Indonesian and Malaysian Affairs, Winter/Summer 1983, pp. 117-160. 
What might have triggered off the movement from Indonesia to Africa?

We have mentioned one possible inducement - the cinnamum trade about two thousand years ago. Another may have been linked to the emergence of powerful states in Southeast Asia which had been spurred on by the growth of trade between the Mediterranean, India and China. One of the earliest states was Funan (first century CE) on the Southeast Asian mainland, which grew rich from traffic crossing the Isthmus of Kra. Funan was followed by numerous smaller polities in Sumatra and Java, all paying allegiance to China. Most notably among these was Kan-to-li in Sumatra, which declined in the $6^{\text {th }}$ century but was followed, in the midseventh century, by its more important successor, Srivijaya. ${ }^{62}$

Srivijaya was for centuries the most powerful of all the island states in the region. It was differentiated from the others by several major factors. To establish an empire that had absolute control over the east/ west sea-routes, Srivijaya - from its capital at Palembang in southern Sumatra - had of necessity, to control the Sunda Strait in the south and the Isthmus of Kra in the north. In addition to protecting its flanks by forming strong alliances with neighbours, Srivijaya built an efficient army of foot soldiers, and a more powerful navy than its neighbours - the latter very probably being made up of ubiquitous Bajo, and ancestral Bugis mariners in addition to the local Orang Laut. In time, according to a Chinese writer, "...Srivijaya had fourteen cities" based on alliances with maritime societies stretching from Java to Kra. ${ }^{63}$ It was said that its prestige among both Indian and Chinese merchants was such that they looked for any excuse they could find to trade in the name of the Srivijayan ruler.

Sumatra was once known as Suvarnabhumi or Suvarnadvipa, 'the Island of Gold'. Not only was it almost the only place in Indonesia where gold was produced in quantity, ${ }^{64}$ but according to the Persian chronicler Ibn Khurdadhbih, writing in the nintgh century, gold had a symbolically important role in the running of the Srivijayan state. In order to demonstrate his debt to Tandru $n$ Luah the God of the Waters of the Sea', the Maharaja would daily throw a bar of gold into Palembang harbour, chanting "Look, there lies my treasure". ${ }^{65}$ When a Raja died, the harbour was dredged, and the gold bars were distributed among the royal family, military commanders, and - if there was any left - the king's other subjects.

62 G Coedès, The Indianised States of Southeast Asia. (3rd Ed. University Press of Hawaii, Honolulu, 1963); OW Wolters, Early Indian Commerce, (Cornell Univ. Press, New York, 1967).

63 OW Wolters, Early Indian Commerce, p. 239.

64 RW van Bemmelen, The Geology of Indonesia Vol. 1, (Gov. Printing Office, The Hague, 1949).

65 KR Hall, Kenneth R. Maritime and State Development in Early Southeast Asia U. of Hawaii. 1985, pp. 80-81. 
Such a powerful demand for gold in Srivijaya may well have been the driving force behind the search for minerals in Africa, and the development of gold mines in Zimbabwe (Sufalah of the Zanj) which were probably opened up by experienced Indian miners who were almost certainly the power behind Sumatra's own ancient mines. ${ }^{66}$ Zimbabwe's gold mining, in the view of Roger Summers, started soon after $600 \mathrm{CE}$ - i.e. at about the time as Srivijaya's rise to power. ${ }^{67}$ Though we have no proof that the gold went to Sumatra or Java, we have evidence that Zimbabwe's gold was shipped abroad from Chibuene, ${ }^{68}$ and other nearby ports within the 'region of Sufalah', in pre-Islamic times. We know, as already mentioned, that merchants from Zanaj/Zabaj (as Sumatra was known at the time of Srivijaya) came to Sayuna in the mouth of the Zambezi in both small and large ships...to exchange ... their goods for those of the Zanj... trafficking in their goods because they understood each other's language.' Perhaps of even greater importance is al-Masudi's passage (CE 956): “...the extremes of the Sea of Zanj and the land of Sofala and the extremes of the country of Waq-Waq ... and this is a land abounding in gold, abounding in miracles, and the Zanj have made it [i.e. the land of Sofala] the seat of their kingdom." ${ }^{69}$ The linkage of the Zanj with the Waq-Waq whom Ferrand, Faublée and others connect with 'Indonesians' gives extra weight to the argument that there was also an Indonesian element in the Zanj. ${ }^{70}$ Bringing the evidence together, the most likely scenario is that in the latter part of the first millennium CE Zimbabwe's gold was shipped from Sufalah of the Zanj, by Indonesian merchants, to the powerful rulers of Srivijaya.

In the exciting early days of Islam, gold may have been the single most important factor providing the wake-up call for Arab and Shirazi adventurers to establish their own powerful city-states on Africa's coast which eventually put a strangle-hold on the old-established trading links between Africa and Indonesia. Following the Cola raids on Srivijaya early in the eleventh century, and gradual changes in political orientation towards China, Indonesian commerce must have been suffering increasing strains. Until finally, did not al-Mujawir (early thirteenth century) say of the mariners who sailed from Madagascar to Africa and Aden in their vessels

66 G Coedès, Op cit., p. 20. Quoting Sylvain Levi: "It was gold that attracted India to the Eldorado of the East" Also... OW Wolters, Op. cit. p. 63 "A search for gold has been regarded by a number of scholars as an important motive for the original interest in Southeast Asia, operating in the last centuries before the Christian era when the movement of barbarians across central Asia deprived the Indians of Siberian gold and in the second half of the first century A.D. when Vespasian cut off supplies of Roman bullion to India."

67 R Summers, Ancient Mining in Rhodesia, (Museum Memoir 3. Salisbury 1969).

68 P Sinclair, Space, Time and Social Formation:etc. (Uppsala 1987). Referred to also in M Horton and J Middleton, The Swahili: the landscape of a mercantile society, p. 79.

69 M Tolmacheva, “The African Waq Waq: Some Questions regarding the Evidence” in Bulletin d'Information Fontes Historical Africanae, No. 11/12 1987/88, p. 12

70 Ibid.,pp.10, 14. 
with outriggers, that '...(they) have now disappeared since their power came to an end and since the route of their travel has been closed.'?

So let's re-cap. Long before the bums, baghlas, and sambuks of Arabia dominated the horizons, and elegant kotirs plied across to Africa from India, the Indian Ocean's shipping lanes were busy with vessels of many other nations: Egyptian 'bottoms' bound for Punt and Ophir; Mesopotamian and Harappan traders clinging to the coast between the Euphrates and the Indus; and Greeks and Romans venturing for the first time far from land as they were carried on the trade winds to southern India and back. In those early days the ships of India stayed mainly inshore, just as Sassanian traders from Persia probably did in the dying days of Roman dominance. ${ }^{71}$ In China, merchant ships, though ubiquitous and often huge, did not sail into the Indian Ocean until the latter part of the first millennium $\mathrm{CE}$.

In fact, the only people who seemed to have roamed the ocean relatively freely throughout that period seem to have been the Austronesianspeaking people of Southeast Asia whose experience as mariners in their island-studded world dates back centuries if not millennia before that of any other people on earth. So if our interpretation of the evidence is correct, and Indonesians were not only familiar with, but settled on the African coast in pre-Islamic - and probably also pre-Bantu - days, how might this effect currently 'established' versions of African history?

There are some things we know; and some things we can only guess at. We know that at some stage Austronesian-speakers discovered and occupied Madagascar, the structure of whose language is closer to that of Easter Island $22500 \mathrm{~km}$ away, than it is to any of the languages of African just $400 \mathrm{~km}$ beyond the Mozambique channel. We are now fairly certain that those who peopled Madagascar were previously well established on the African coast, accounting for the rich, deeply entrenched mix of African vocabulary, customs and genes in Madagascar. If that was the case, the odds strongly support the conclusion that the Afro-Indonesian society on the mainland was both older, larger, and more racially varied than is generally acknowledged (if their presence is acknowledged by modern historians at all!); and that the polygenetic society in question was none other than the various tribes of 'Zanj'.

Such a scenario also lends credence to the hypothesis proposed by M. Horton $^{72}$ and others that the rapid southward spread of Early Iron Age (?100 to c.500CE) pottery, almost as far as Durban in South Africa, was due to it being carried by sea, rather than by migrating tribesmen moving slowly overland ... and likewise, many years later, the spread of Tana-

71 D Whitehouse, "Sasanian Maritime Activity" in 'The Indian Ocean in Antiquity' ed. J. Reade. 1988. Whitehouse points out that from CE $226-651$ the Sasanians who ruled Iran and, eventually, adjacent countries from the Red Sea to the Indus, played a major role in the trade to Asia. Sasanian dominance may have contributed to the decline in Arab shipping in the years leading up to the end of the sixth century.

72 M Horton and J Middleton, The Swahili: the landscape of a mercantile society, p.38. 
ware' (?500-1000CE ... which must have been carried by sea to reach the Comoros and Madagascar). The rapid movement of people and ideas down the coast would have radically effected inland locations in southern Africa such as Broederstroom, which we know, from cowrie shell evidence, ${ }^{73}$ must have been in contact with the coast. Are we right in assuming that these early southern sites 'belong' solely to anomalous advance parties of migrating Bantu? Or might some more mobile elements of a mixed mariner race have been primarily responsible?

Once Madagascar was populated there is no reason to think it was then isolated from the rest of the world. Indeed, there must have been constant activity in the Bahr az Zanj between Madagascar and the mainland. Not only is this evident from the range of African influences found in Madagascar; but - more interestingly - when one looks at the reverse flow, the many cultural elements in Africa that seem to have their roots in the 'Great Isle'. Raymond Kent wrote much about this two-way traffic in his Early kingdoms in Madagascar ${ }^{74}$ with particular reference to the Shona, Venda and other Central African people radiating around Zimbabwe (which is, incidentally, the very region considered by al-Masudi to have been the 'the seat of the kingdom' of the Zanj): and I have expanded on this in my Phantom Voyagers. Strong though the evidence is, it is seldom, if ever, taken into account in studies of Central African cultures, particularly those of Zimbabwe, Nyanga, the Upemba depression, etc. But it should be. Without it we are left with distorted history.

Music and musical instruments provide interesting and important links, particularly noticeable in Central Africa, between Indonesia and Africa. For instance, in the lower Zambezi region, are heard the haunting sounds of the Nyungwe panpipes ${ }^{75}$ - instruments identical in form to those of Vanuatu and the Solomon Islands, ${ }^{76}$ but which were also once played in Java, Flores, Timor and New Guinea. ${ }^{77}$ But the best known 'African' instrument played across a great swathe of Africa from Mozambique to Senegal (but which seems to have made it to Madagascar only in a primitive form) is the xylophone, which most musicologists now accept as

73 R Mason, Background to the Transvaal Iron Age - New Discoveries at Oliphantspoort and Broederstrom. J. of the Inst. Of Mining and Metallurgy. Jan 1974 p. 212. The evidence is minimal; but the cowrie found was of a type that came from the Maldives.

74 R Kent, Early Kingdoms in Madagascar 1500 - 1700 (Holt, Rinehart and Winston, New York, 1970).

75 A Tracey, "The Nyanga Panpipe Dance" in African Music, Vol. 51971.

76 H Fischer, "Sound Producing Instruments in Oceania" Inst. of PNG Studies, Nos. 384 and 389, 1983 p. 207.

77 J Kunst, Music in Java. (The Hague, 1970) pp. 30, 366, 376; AM Jones, "Panpipes and the Equipentatonic Pitch" in African Music, Vol. 1, 1980. 
having originated in Indonesia. ${ }^{78}$ It is particularly noteworthy that about 500 years ago Africa's pre-eminent xylophonists, the Chopi, who now live near the mouth of the Limpopo, broke away from the Karanga, the Shona clan considered to have been the ancient custodians of The Great Zimbabwe. ${ }^{79}$ Such links between The Great Zimbabwe, Madagascar and Indonesia are of prime historical importance, and should not be left mouldering in the shadows.

At some point Indonesians must have sailed round the Cape and up to West Africa. Those who doubt whether this was possible should take note of the voyage of Philip Beale's Samudra Raksa, already mentioned. ${ }^{80}$ Though Al-Biruni asserted that the Indian Ocean stretched "... from Aden to Sufalah of the Zanj, beyond which no ship ventures because of the great risks involved... [for] beyond this point it joins the Western Ocean", he may have been referring only Arab or Persian ships.

Although there is not room here to expand at length on probable Indonesian influences beyond the Cape it is important to make some mention of the many hints of Southeast Asian activity that are apparent in West Africa - particularly Nigeria.

We have already mentioned the xylophone; and there is no need to elaborate on Father Jones' famous story of his friend in Sierra Leone who was able to play a Cambodian box-xylophone and his own Mandinka (Sierra Leone) instrument as though they were one. ${ }^{81}$ The similarities, and his subsequent musical evidence, were compelling. Other musical analogies can be made; e.g. between the Igbo ekere-mba (drum xylophone) and the Thai kong tock; ${ }^{82}$ between the eclectic designs of message gongs; 83 between virtually identical bar-zithers in the Congo, Mozambique, Madagascar - and Sulawesi; ${ }^{84}$ and possibly also the development of tuned double iron gongs used in West Africa, and ancient Zimbabwe. ${ }^{85}$

78 AM Jones, "The Influence of Indonesia: the Musicological Evidence Reconsidered" in Azania, 4, 1967; AM Jones, Africa and Indonesia (2nd Edition, EJ Brill, Leyden, 1971) J Kunst, "A musicological argument for cultural relationship between Indonesia -probably the Isle of Java - and Central Africa" in Proceedings of the Musical Association. Session LX11 1935/36.

79 H Tracey, The Chopi, (Oxford University Press, Oxford, 1948) p. 123, Also ref: pp. 9, 107 , and 137.

80 Google Borobudur Ship for full information on the expedition

81 AM Jones, Africa and Indonesia, p. 1.

82 JN Lo-Bamijoko, "Classification of Igbo Musical Instruments, Nigeria" in African Music, Vol. V1, 1987: Illustration of S.E. Instruments can be found on the internet.

83 JF Carrington, "A comparative Study of some Central African Gong-Languages"in Memoires - Collection in-8 Tome XV111 fasc 3 Institut Royal Colonial Belge. Section des Sciences Morales et Politiques, (Brussels 1949) p. 119 and illustrations.

84 R Dick-Read, The Phantom Voyagers: Evidence of Indonesian Settlement in Africa in Ancient Times. p. 133.

85 Ibid., p. 135; R Dick-Read, Sanamu: Adventures in Search of African Art. (Rupert HartDavis, London 1964) pp. 148-150. 
Elephantiasis (wuchereria Bancroftii) is a disease portrayed in early Nok sculptures, ${ }^{86}$ and, very poignantly, in a famous twelfth or thirteenth century Ife terracotta. ${ }^{87}$ Tropical medicine experts say that elephantiasis originated in the coastal swamps of Southeast Asia; but more than that - they say it is unlikely, owing to the nature of its transmission, to have spread across Africa from person to person overland; but more likely to have been carried to West Africa directly by infected people. ${ }^{88}$

Plantains, yams and cocoyams that have been grown in West Africa for centuries, since before European contact, are Southeast Asian varieties. ${ }^{89}$ Musa $A A B$ and Southeast Asian varieties of yams which came to dominate the subsistence of most sub-Saharan West Africans may have made possible a huge surge in the population - some say, even, making the Bantu migrations through the forest regions possible. It is still debated whether they were introduced in East Africa from where they spread to the west; but there are many good reasons for thinking that these plants were introduced independently in West Africa. ${ }^{90}$

Likewise maize. Twelfth-century floor tiles found in Yorubaland buried $4 \mathrm{~m}$ beneath the surface were decorated with impressions of 'corn-cobs'. ${ }^{91}$ Maize is a hybridised Mexican plant that was most likely carried from the Americas to Southeast Asia by Polynesians along with other plants (sword-bean; sweet potato; gourds). ${ }^{92}$ Was it carried to Yorubaland by the same people who introduced plantains and yams? We can only guess.

Among Africa's best known icons are its 'bronzes'; but where did the complex technologies by which they were made originate? Most experts believe the processes of finding, smelting, and blending disparate metals to make bronze - and casting by the intricate lost-wax process - to have

86 B Fagg, Nok Terracottas (National Museum, Lagos, 1977), Plate 121

87 F Willett, IFE in the History of West African Sculpture, (Thames and Hudson, London, 1967), p. 95, Plate 39.

88 BR Laurence, "Elephantiasis and Polynesian Origins" in Nature. 219 Aug. 1968.

89 GP Murdock, Africa: Its People and their Culture History, (McGraw-Hill Book Company Inc. New York 1959).

90 NW Simmonds, and RH Stover Bananas 1987; J Vansina, Paths in the Rainforest. (University of Wisconsin Press, Wisconsin, 1990); L Vrydaghs, E de Langhe and others: "Phytoliths: An Opportunity to Rewrite History" (European Meeting on Phytolith Research - Madrid, 1996). None of these specifically state that these plants were introduced on the West coast, but in correspondence with a third party, Simmonds is said to have favoured that view. There are many arguments against Murdoch's (and Oliver's) view that they were carried overland from the east.

91 F Willett, IFE in the History of West African Sculpture, p.108.

92 CR Stonor and E Anderson, "Maize among the Hill People of Assam"in Annals of the Missouri Botanical Gardens, Vol. 36, 1949: GF Carter, "Plant Evidence for Early Contacts with America" in Southwestern J. of Anth. Vol. 6. 1950: GF Carter, "Movements of People and Plants across the Pacific Ocean in Ancient Days" in Proc. of the Pacif. Sc: Cong. 1962. GF Carter, Maize into Africa. Anthro. Jour. of Canada, 1(2), 1963, pp. 3-8 1963; GF Carter, "Archaeological Maize in West Africa" in MAN. No. 95, May/June 1964. 
been introduced from outside. ${ }^{93}$ Igbo Ukwu, where sub-Saharan Africa's earliest (ninth century) and most accomplished bronze castings were found, lies a thousand kilometres from the main trans-Saharan trade routes, ${ }^{94}$ but within a few kilometres of the navigable channels of the Niger and Cross Rivers. Taken as an isolated instance it might be questionable whether people from Indonesia (where cire perdue casting was much in evidence at that time) would have introduced such technology so far from home. ${ }^{95}$ But in conjunction with other factors, and Srivijaya's known interest in prospecting for metals elsewhere in Africa, it would actually have been easier for expert metallurgists to have reached the Igbo region by sea, rather than across deserts and through hostile forests from the Middle East or the Mediterranean.

Now consider Ifa divination that is deeply engrained in Yoruba culture and central to its religion. ${ }^{96}$ How is it that Ifa's $4 \times 4 \times 4 \times 4$ structure, with its 256 named variations, is so similar in all its essentials to Bwe divination in several Micronesian islands on the other side of the world? ${ }^{97}$ Although the ultimate origins of both systems almost certainly lie in China, ${ }^{98}$ 'experts' airily declare that the African system must have been introduced across the Sahara by Arabs who practice the roughly similar al-raml. Although the simpler, more recent, Yoruba atimi divination unquestionably had its origins in al-raml, William Bascom, the leading writer on the subject, had no firm thoughts about such a provenance for Ifa. ${ }^{99}$ For one thing it would seem that Ifa predates, perhaps by a long way, the penetration of Yorubaland by Arabs; and secondly it is much more complex and involved than al-raml as practiced in the Sahara. The Yoruba were not land-locked: they numbered among them fine seamen who travelled long distances in their open canoes - sometimes down the coast as far as the Congo, so it is said. Contact with 'god-like' mariners looming over the southern horizon in sturdy ships with billowing sails was an altogether more likely channel for important new ideas with deeply religious significance, than Arab traders (who were generally terrified of being eaten by 'Black cannibals') arriving from the Saharan wastes. (Of the 52 Arab chroniclers who wrote about West Africa from mid-ninth to

93 F Willett, IFE in the History of West African Sculpture, pp. $126-127$

94 N Levtzion and JFP Hopkins, Corpus of Early Arabic Sources for West African History. Cambridge University Press, Cambridge, 1981).

95 T Shaw, Unearthing Igbo-Ukwu, (Oxfoprd University Press, Ibadan, 1977).

96 W Bascom, Ifa Divination: Communication between Gods and Man in West Africa (Indiana University Press, Indiana, 1969).

97 W Lessa, "Divining from Knots in the Carolines" in J. of the Polynesian Soc. 1959, pp. 188-203.

98 H Wilhelm, Correspondence 24/4/75 re: Ifa and Ch. 'Book of Fate'. This is a fairly widely held belief, confirmed to me in correspondence by the Sinologist, the late Hellmut Wilhelm. Conversely the Arabist, the late AFL Beeston,. confirmed to me in correspondence $(25 / 3 / 60)$ that the $4 \times 4 \times 16$ structure of Ifa and Itimi, or any of the other systems supposedly based on al-raml (Malagasy sikidy, or others in Central Africa) was based on any known Arabic mathematical system.

99 William Bascom - personal correspondence. 
the late-fourteenth century, only one is known to have set eyes on, let alone travelled down, the Niger river - Ibn Battuta, who canoed down a short stretch of the middle-Niger in about 1350 by which time Yoruba society had long since reached highly sophisticated levels). ${ }^{100}$

Followed to its logical conclusion, if plantains, yams, bronze-making, lost-wax casting, xylophones, other musical instruments, elephantiasis, and an important divination system were introduced by Southeast Asians, which seems not only possible but probable, we should at least accept the possibility that the same might have applied to other aspects of their culture. These would include glass-making; ${ }^{101}$ various bead making techniques (drawn tubes, for instance); ${ }^{102}$ some games ('mancala', 'wari); ${ }^{103}$ cowrie shells both as decoration and as money (cowries later became a profitable item of Arab trade from the Maldive Islands); and the forty-odd culture traits proposed by Professor J. Hutton - ranging from the underlying philosophies behind head-hunting, through cannibalism, to burial customs and promotion of fertility. ${ }^{104}$

Lastly, it is quite possible that iron-smelting technology came to Africa from Indonesia; though this would need much more research. Madagascar never had a stone age, or even a bronze age. Since the earliest inhabitants arrived it has had an iron-age culture. Piston-bellows of an Indonesian variety used to be common in Madagascar, and although bellows in Africa are usually bag- or bowl-bellows, piston-bellows were apparently once used in West Africa. ${ }^{105}$ Africa's inter-lacustrine region, where some of the earliest iron-smelting sites are to be found, could as easily have been reached from the East Coast as by migration up the Nile through the Sudd; and the location of many of the most ancient sites in western Africa (c.450 BCE) would have been more accessible up rivers from the sea than they would have been overland ${ }^{106}$ (even Taruga, one of the earliest sites, though far inland, is approachable from tributaries of the Benue and Niger rivers). ${ }^{107}$ We are making a massive mistake in assuming that all those elements of African culture that came from foreign fields came either from the Mediterranean or the Middle East. We tend to forget the

100 N Levtzion and JFP Hopkins, Corpus of Early Arabic Sources for West African History. (Cambridge U.P. 1981).

101 HAS Johnston, The Fulani Empire of Sokoto. (Oxford University Press, Oxford, 1967) p. 312; (Bida) Kurinsky, Samuel. The Glassmakers. Hippocrene Books, Kegan Paul 1991 (Bida) Nadel, S.F. The Field Diaries of an Anthropologist in Nigeria 1935 - 36 Ed. Roger Blench (Available on the I'net) p. 55.

102 Jamey Allen, Correspondence on beads.

103 C Schuster and E Carpenter, Patterns that Connect (H.N. Abrams, New York) p.281 - and other references available on the internet; E.g. Congklak:Traditional Game of Indonesia: See Also:- E Torday, On the Trail of the Bushongo. 1925.

104 JH Hutton, "West Africa and Indonesia: A Problem in Distribution". The Everard im Thurn Memorial Lecture. Scottish Anth. and Folklore Soc. 1947.

105 AM Jones, Africa and Indonesia, pp.201-203.

$106 \mathrm{~J}$ Vansina, Paths in the Rainforest. (U. of Wisconsin. Wisconsin, 1990), Map. p. 59 107 B Fagg, Op.cit. See map of Jos Plateau at very end of the book. 
advanced state of culture in maritime Southeast Asia, particularly during the Srivijayan era, and the age-old brilliance of Indonesian seamen.

Africa's historians should stand back, and take a fresh look at these problems with this in mind. 